\title{
Sproglærererfaringer fra skolenedlukningen i foråret 2020
}

\author{
Mette Vedsgaard Christensen, VIA University College \\ Alice Bonde Nissen, VIA University College \\ Morten Gustenhoff, VIA University College
}

\section{Abstract}

I denne artikel præsenterer vi fundene fra en undersøgelse af fremmedsprogslæreres erfaringer med undervisning i grundskolen under corona-nedlukningen i foråret 2020. Data består af surveydata fra ca. 170 respondenter om brug af teknologier, rammer for undervisningen og undervisningens organisering. Seks lærere blev udvalgt til opfølgende interviews. Undersøgelsen viser som forventet, at mange lærere fandt det udfordrende at undervise i fremmedsprog under nedlukningen: Både skoledagens skemalagte struktur, identificering af teknologi, der kan understøtte elevernes sprogtilegnelse, klasseledelsen og relationsarbejdet blev udfordret, men lærerne rapporterer også om erfaringer med at svare på disse udfordringer, erfaringer, som indgår i deres sprogdidaktiske praksisser også efter nedlukningen. Vores artikel viser således, at fremmedsprogsundervisningen både blev udfordret og udviklet under nedlukningen, og vi præsenterer fund om nye mundtlighedspraksisser i sprogundervisningen, som er et tilbagevendende tema i vores data. Vi diskuterer vores fund både i lyset af aktuel forskning $\mathrm{i}$ fremmedsprogsdidaktik og digitale teknologier i grundskolens undervisning.

\section{Engelsk abstract}

This paper presents findings from a study of Danish foreign language teachers' experiences during the spring 2020 corona lockdown. The data consists of survey data collected from approximately 170 respondents, detailing the usage of technology along with wider organizational aspects. Six teachers were selected for subsequent interviews. As expected, the study shows that a large number of teachers found it difficult to teach their foreign language classes during the lockdown: school day timetables, classroom management, and identification of relevant digital technologies brought challenges. Yet, the teachers also found remedies for these challenges. Such experiences and insights were later integrated into language pedagogical practices after the lockdown. This paper thus demonstrates that foreign language teaching was both challenged and developed during the lockdown. Examples of these insights are presented, focusing particularly on oral practices in foreign language classrooms, a recurring theme within the data. The findings are discussed in the context of current research in second language acquisition and the usage of digital technologies in Danish primary and lower secondary classrooms. 


\section{Indledning}

Genstanden for undersøgelserne i dette studie er fremmedsprogslærernes selvrapporterede erfaringer og praksisser under skolenedlukningen i foråret 2020, og vores artikel bidrager således både til den hastigt voksende mængde forskningslitteratur om erfaringer med digital undervisning under coronaepidemien, men også til en bredere diskussion om digitalisering af undervisning i almindelighed og af fremmedsprogsundervisningen i særdeleshed. Empirisk tages der afsæt i undersøgelser af digitalisering og digitaliseringsprocesser i undervisning og skole bredt forstået (Bundsgaard et al. 2018), men også i fagdidaktiske perspektiver på teknologi og digitalisering i fremmedsprog (Golonka et al., 2014; Lee, 2019; Zhang \& Zou, 2020). Undersøgelsens overordnede teoretiske udgangspunkt finder vi i fremmedsprogspædagogikkens sociokulturelle syn på læring, hvor begreber om dialogiske, elevinddragende undervisningsformer som rammen for udvikling af kommunikative kompetencer er centrale (Hymes, 1972; Kramsch, 2006), men også i læremiddel- og opgavedidaktikforskning, som anlægger et socialsemiotisk perspektiv på læremidler og digitale teknologier (J. J. Hansen, 2010; T. I. Hansen, 2012). Det socialsemiotiske perspektiv tilbyder analysegreb til og begreber om læremidlernes særlige kombination af form og indhold og deres muligheder for at skabe interaktion mellem elever og indhold. Undersøgelsen skriver sig dermed ind i både aktuel forskning i digitalisering og lærermidler, men bidrager med et særligt fremmedsprogsdidaktisk perspektiv på begge, når vi stiller spørgsmålet: Hvilke erfaringer gjorde fremmedsprogslærere sig med brug af digitale teknologier i forbindelse med skolenedlukningen i foråret 2020?

\section{Baggrund}

\section{Digitale teknologier i pædagogiske kontekster}

Som en del af en overordnet digitaliseringsstrategi er undervisningen i danske skoler de seneste år blevet digitaliseret (Bundsgaard et al., 2018). Resultatet er, at computermedierede læremidler (især fra mellemtrinnet og op) og digitaliserede styrings- og kommunikationsteknologier præger skolens praksisser og dermed elever og læreres hverdag i alle fag. Før skolerne lukkede ned i foråret 2020, var digitalisering altså allerede en del af den danske skolehverdag, og digitaliseringsprocessen er $\mathrm{fx}$ undersøgt i de såkaldte Demonstrationsskoleforsøg, hvor en gruppe forskere undersøgte både effekter af og praksisser med digitale læremidler, som de udviklede sig på tre skoler. Deres undersøgelser fokuserer både på de fagdidaktiske, organisatoriske og teknologiske perspektiver i digitaliseringen. De fagdidaktiske undersøgelser viste (Bundsgaard \& Hansen, 2018; Slot et al., n. d.), at fagene dansk og matematik var præget af et udbredt traditionelt undervisningsmønster med en del formidling, heraf mest individuelt elevarbejde og mange træningsopgaver. Omvendt forholdt det sig med kulturfag og naturfag, som adskilte sig ved at have flere, virkelighedsnære fagligt konstruerede problemopgaver, mens træningsopgaverne fyldte mindre. Demonstrationsskoleforsøget konkluderede ydermere, at lærerne primært anvendte it som et basalt redskab til "produktion, formidling og elevers træning (bl.a. basisprogrammer, læringsapps, interaktive tavler og digitale kameraer)" (T. I. Hansen \& Bundsgaard, 2016, s. 21), men kun i begrænset omfang til at håndtere samarbejde og processtyring. De ovennævnte undersøgelser fokuserer ikke specifikt på digitaliseringens konsekvenser for fremmedsprogsundervisningen, men danske undersøgelser af teknologibrug i modersmålsfaget rummer indsigter med sprogdidaktiske perspektiver. To danske studier - en forskningskortlægning (Tannert \& Berthelsen, 2020) og en empirisk undersøgelse af læremidler i danskfaget (Bremholm et al., 2017) tegner tilsammen et komplekst billede af digitale teknologier i danskundervisningen: På den ene side rummer digitale læremidler muligheder og potentialer for kooperative arbejdsformer $-\mathrm{fx}$ i forbindelse med skrivning (Tannert \& Berthelsen, 2020) - og muligheder for at skabe konkrete kommunikative forbindelser til verden uden for klasseværelset, men den konkrete kontekstualisering af digitale teknologier kan også betyde individualiseret undervisning, der fokuserer på at træne begrænsede 
færdigheder (Bremholm et al., 2017). Studierne viser altså vigtigheden af, at undersøgelser af digitale teknologier kontekstualiseres, så man bedre får øje på, hvad teknologierne rummer af udfordringer og potentialer for den specifikke didaktiske praksis, de indgår i.

Brugen af digitale teknologier i fremmedsprogsundervisningen udvikler sig i takt med udviklingen af og forandringen i teknologierne - både i og uden for skolens undervisning. Således spiller både værkøjer som tekstbehandlingsprogrammer og præsentationsprogrammer, men også oversættelsesmaskiner og sociale medier en rolle i fremmedsprogsundervisningen (Caviglia, Dalsgaard, Boie \& Thomsen, 2021; Boie, Dalsgaard \& Caviglia, 2020). Et ældre forskningsreview, som undersøger effekterne af at erstatte forskellige teknologier som $\mathrm{fx}$ analoge tavler med interaktive tavler, finder, at de positive effekter på elevernes sprogfærdigheder er begrænsede, dog med udtale som den eneste sikre undtagelse (Golonka et al., 2014). Nyere forskningsoversigter tager højde for, at brugen af digitale teknologier ikke bare rummer mulighed for at flytte kendte aktiviteter til nye medier og værktøjer, men også potentialer for at omdefinere interaktionsformer mellem elever og mellem elever og indholdet. Således viser et metastudie af Zhang \& Zou (2020), at de fleste elever kunne forbedre deres færdigheder i at tale, lytte, skrive samt deres ordforråd og motivation, når fx mobile teknologier, spilteknologier og sociale medier indgik i fremmedsprogsundervisningen med det formål at understøtte interaktion eller skabe nye organiseringsformer i undervisningen. Nye organiseringsformer indebar fx såkaldte flippede undervisningsformer, mens mobile teknologier og sociale medier både øgede elevernes interaktion med hinanden og med læreren.

Lee (2019) har i et metastudie undersøgt digitale teknologiers potentialer for at kontekstualisere fremmedsprogsundervisningen. Kontekstunderstøttende teknologier skal forstås som teknologier, der i forskellige grader involverer en eller flere af følgende affordanser (vores oversættelser): bærbarhed, social interaktion, kontekstrettethed, forbundethed og individualitet (Squire \& Klopfer, 2007 i Lee, 2019, s. 4). Bærbare teknologier, som fx mobile teknologier, giver eleverne mulighed for at bevæge sig mellem steder og imellem formelle og uformelle scenarier, og de muliggør både stedbaseret og steduafhængig læring. Social interaktion fremmer samarbejde og sproglig interaktion mellem elever eller mellem elever og aktører i virkelighedsnære scenarier. Kontekstrettethed muliggør situeret læring, og rummer muligheden for at forbinde elever med andre elever, elever med lærere og sproglige og indholdsmæssige ressourcer, og det muliggør sproglig og indholdsmæssig stilladsering og her-og-nu feedback (just-in-time support). Endelig betyder den individualiserede affordans, at teknologien indretter sig efter elevens individuelle behov og læring. Metastudiet adresserer en særlig fremmedsprogsdidaktisk udfordring, nemlig at fremmedsprogstilegnelsen foregår i et klasseværelse afskåret fra det sprogfællesskab, hvor målsproget bruges. Eleverne kan opleve fremmedsprogsundervisningen som en slags andenhåndsoplevelse, og derfor kan fremmedsprogslæring opfattes som mindre relevant. Men brugen af de såkaldte kontekstunderstøttende teknologier ser ud til at ændre på billedet: Metastudiet finder både positive effekter på elevernes sproglige udvikling og på de affektive aspekter. Studiet konkluderer altså, at digitale teknologier kan sætte rammer for elevernes læring og brug af fremmedsproget i meningsfulde sammenhænge, hvor de interagerer mere med hinanden og med andre sprogbrugere, og hvor forbundetheden med hinanden og med læreren giver mulighed for støtte, når den behøves, hvilket øger elevernes motivation for og dermed deres færdigheder i fremmedsprog. Disse fund fra den internationale litteratur står i kontrast til danske studier af brugen af digitale teknologier i fremmedsprogsundervisningen. Her viser studier, der dog specifikt fokuserer på grammatikundervisningen, at anvendelsen af digitale teknologier i fremmedsprogsundervisningen ofte medfører opgaver af individuel træningskarakter (Kabel et al., 2019), og at mængden af denne type opgaver tilsyneladende øges med digitalisering (Bundsgaard \& Hansen, 2018; Kabel et al., 2019). Disse undersøgelser tyder på, at fremmedsprogslærere i den danske grundskole ikke har erfaringer med at bruge digitale teknologiers potentialer for at kontekstualisere fremmedsprogsundervisningen, når grammatik er i fokus, men nærværende undersøgelse kan bidrage med et bredere perspektiv på læreres erfaringer med og praksisser for anvendelse af digitale teknologier. 
Vores undersøgelse skriver sig også ind i litteraturen om de samlede pædagogiske og didaktiske konsekvenser af corona-nedlukningerne under pandemien i 2020 og 2021. Undersøgelserne viser - ikke overraskende - at nedlukningerne har haft negative konsekvenser for den oplevede kvalitet i undervisningen, og hos mange også for den oplevede studieintensitet (Georgsen \& Qvortrup, 2021). Nedlukningen betød, at digitale teknologier kom til at spille en central rolle for afvikling af undervisning på alle niveauer, dermed blev lærer- og elevkompetencer på dette område prøvet. Men undersøgelserne viser også, at lærere, elever og studerende bruger muligheder for fx mere elev- og studentercentreret undervisning, friere arbejdsformer og ikke mindst nye og flere feedback-former, som den digitaliserede undervisning giver muligheder for. I det følgende vil også denne undersøgelses pointer bidrage til den voksende litteratur om både udfordringer og potentialer ved undervisning med digitale teknologier i fremmedsprogsundervisningen.

\section{Det mundtlige klasserum}

Mundtlighed har længe været centralt for forskning og undervisning i fremmedsprog (Hymes, 1972), men undervisning i og med mundtlighed udgør også et voksende forskningsfelt i den fagdidaktiske litteratur om modersmålsundervisning (Høegh, 2018; Penne \& Hertzberg, 2019). I både fremmedsprogs- og modersmålsundervisningen spiller mundtlighed og mundtlige genrer vigtige roller som både indhold (fx argumentation eller udtale) og mål (fremlæggelser og dialoger), ligesom mundtlige genrer i begge sammenhænge ses som veje til sproglig og faglig udvikling: Man lærer sprog, og man lærer om sprog ved at bruge sproget i forskellige kontekster med forskellige grader af opmærksomhed på mundtligheden (Burns, 2019). Fælles for både fremmedsprogs- og modersmålsundervisningen er også en demokratiseringsdiskurs, og i begge sammenhænge vægtes elevdeltagelsen i undervisningen.

Mundtlighed i fremmedsprogsundervisningen er tæt knyttet til begrebet om kommunikativ kompetence (Hymes, 1972; Kramsch, 2006) og dermed til et sprog- og læringssyn, der vægter sprogets funktionelle brug højere end viden om sprogets strukturelle opbygning. Begrebet om kommunikativ kompetence indebærer dermed et bredt syn på mundtlige færdigheder: både pragmatiske, (socio)lingvistiske, kommunikationsstrategiske og (inter)kulturelle kompetencer indgår i begrebet (Canale \& Swain, 1980; Hedge, 2000, s. 46-53; Andersen et al, 2015, s. 14; Lund, 2015, s. 106). Det kommunikative paradigme fordrer elevdeltagelse, hypoteseafprøvning og gensidige bidrag mellem lærere og elever i undervisningen, men sigter også mod at ruste eleverne til deltagelse i uddannelse og samfund bredt forstået. Fremmedsprogsundervisningen har altså resonans med bredere pædagogiske idealer, fx Folkeskolens formålsparagraf.

En ny forskningskortlægning peger imidlertid på udfordringer for det kommunikative paradigme og for undervisning i mundtlighed specifikt (Andersen, 2020). Fx påvirkes elevers muligheder for at deltage i mundlige genrer af sproglige forhold (deres kompetencer på fremmedsproget), men også sociale og psykologiske forhold spiller ind. Krashens begreb affective filter (Krashen, 1982) ses ofte som en tidlig teoretisk formulering af denne problemstilling i fremmedsprogstilegnelse. For mange elever er der en naturlig usikkerhed og sårbarhed forbundet med at tale et fremmedsprog - særligt foran hele klassen. Skal eleverne træne målsproget mundtligt i undervisningen, er det altså essentielt, at klasseværelset fremstår som et trygt sted at øve sig. Denne orientering mod elevernes følelsesmæssige balance som forudsætning for mundtlighed er siden Krashen (1982) blevet koblet til bredere diskussioner om sprogelevers motivation og selvtillid (Piniel \& Csizér, 2013) og er blevet en fremmedsprogsdidaktisk hjørnesten, der fokuserer på nødvendigheden af motivation, lyst og mod til at bruge sprog for at lære sprog. Dette ses i forskningen gennem fremkomsten af begreber som willingness to communicate (WTC) (MacIntyre, 2007), og det ses også i fremmedsprogsdidaktiske lærerbøgers lavpraktiske greb og tilgange til at skabe trygge klasseværelser (Harmer, 2015; Lightbown \& Spada, 2013; Scrivener, 2011). Samlet set er der altså mange spørgsmål om motivation, som fremmedsprogsdidaktikken har måttet integrere i sit ideal om kommunikativ kompetence, hvilket også afspejles i den medførte kommunikative sprogundervisnings (ofte benævnt ved den engelske forkortelse CLT) metoder og tilgange (Anderson \& 
Larsen-Freeman, 2011, s. 123; Burner \& Kverndokken, 2019, s. 21-22). Organiseringen af klasseværelset i mindre grupper af elever, der arbejder med kommunikative problemløsningsopgaver, bredt kendt som tasks (Willis, 1996; Pedersen, 2001), får dermed ofte det dobbelte formål at (1) øge hver elevs taletid og (2) gøre det mere følelsesmæssigt overkommeligt at bruge målsproget.

De ovenfor citerede fremstillinger og studier af mundtlighed og kommunikative kompetencer bygger på forståelser og praksisser, der indebærer elevers og læreres fysiske tilstedeværelse og interaktion i klasserum. I fremmedsprogsundervisningen opfattes kommunikativ sprogundervisning dermed tit som synonym med par- eller gruppearbejde, fx når det får form som task-baseret undervisning, arbejdsformer, der også betragtes som greb til at øge motivationen for sprogbrug (Pérez, 2016). Disse perspektiver er særligt interessante i denne undersøgelse, da vores analyser har lærererfaringer med undervisning i mundtlighed og mundtlige genrer i forbindelse med skolenedlukningerne som genstand. Vores undersøgelse bidrager dermed til den eksisterede viden om og konceptualisering af mundtlighed med nye perspektiver på mundtlighedens muligheder og begrænsninger i lyset af den digitaliserede undervisnings affordanser.

\section{Teoretiske og metodiske rammer}

Vores undersøgelse trækker på to typer af data: kvantitative og kvalitative data fra en surveyundersøgelse gennemført i sommeren 2020 og semistrukturerede interviews (Kvale \& Brinkmann, 2015) med seks sproglærere. Formålet med at indsamle og analysere både kvantitative og kvalitative data og dermed metodetriangulere er at øge validiteten af vores konklusioner, og muligheden for at lade de forskellige datatyper og analysestrategier berige hinanden giver os mulighed for at levere mere detaljerede svar på vores undersøgelsesspørgsmål om fremmedsprogslærernes erfaringer (Frederiksen, 2013). Lærerne blev udvalgt på baggrund af deres svar i surveyundersøgelsen (mere om det nedenfor), og lærerinterviews blev gennemført i september og oktober 2020. De surveydata, som indgår i denne undersøgelse, er indhentet i forbindelse med en større kortlægning af brugen af digitale teknologier i fremmedsprogsundervisningen i grundskolen. I forbindelse med skolenedlukningen i foråret 2020 designede vi et tillæg til kortlægningen, som specifikt indsamlede data om lærererfaringer fra nedlukningen.

Vores metodiske overvejelser i forbindelse med designet af surveyundersøgelsen tager udgangspunkt i en socialpsykologisk opfattelse af spørgeskemaundersøgelser som socialt konstruerede situationer, hvorfor især den konkrete formulering af spørgsmål er et central metodisk spørgsmål (K. M. Hansen, 2012). En spørgeskemaundersøgelse er grundlæggende en måling, derfor er spørgsmål om målingens validitet og reliabilitet centrale for resultaternes kvalitet. I vores undersøgelse tilstræber vi validitet ved grundigt at overveje forholdet mellem den teoretiske ramme om undersøgelsen og de måder, vi operationaliserer teorien til spørgsmål. Disse overvejelser angår både, hvad vi spørger til (vores hypoteser, som undersøgelsen skal give svar på), og hvordan vi spørger (den konkrete formulering af spørgsmålene). Vores undersøgelse afdækker bredt set fremmedsproglæreres brug af digitale teknologier i deres undervisning. I spørgeskemaformatet har vi operationaliseret dette undersøgelsesspørgsmål til et spørgsmålsbatteri, der undersøger, hvilke teknologier lærerne kender og bruger, i hvilken faglig kontekst de bruger dem, samt hvilken klasserumsorganisering og hvilke arbejdsformer de indgår i. Vores undersøgelsesspørgsmål er således informeret ikke blot af læringsteori, men også af indsigter fra fx demonstrationsskoleforsøget, hvor anvendelsen af teknologier og konkrete klasserumsorganiseringer hang sammen. Vi valgte at spørge både i lukkede, kvantificérbare formater, som er praktiske, når man skal håndtere større datamængder, men som også udelader en del information, og i åbne formater, som til gengæld kræver mere analytisk arbejde. I alt svarede 250 sproglærere på vores spørgeskemaundersøgelse, men da coronadelen var et frivilligt tillæg til undersøgelsen, har denne et lidt lavere antal respondenter: 171 har afgivet svar i denne del af undersøgelsen. 
De kvalitative svar har vi efterfølgende kodet med udgangspunkt i begreber fra den socialsemiotiske lærermiddelteori, og nedenfor gennemgår vi kort de overordnede resultater. På baggrund af de afgivne svar kontaktede vi efterfølgende ni udvalgte lærere, hvis svar vi fandt repræsentative for afdækningen: Tre af lærerne angav, at nedlukningen overvejende havde medført udfordringer og forhindringer for undervisningen, seks angav både negative og positive erfaringer. Blandt respondenter med positive erfaringer vægtede vi at kontakte respondenter, der angav at have gjort sig erfaringer med undervisning i mundtlighed, men også med klasseledelse og organisering i det hele taget. Seks af lærerne svarede positivt tilbage, dog responderede kun en af lærerne med overvejende negative erfaringer på vores henvendelse. Vi udarbejdede en interviewguide og gennemførte efterfølgende seks interviews af mellem 30 og 50 minutters varighed. Analyseprocessen af både survey- og interviewdata var en kollaborativ proces. De åbne svar fra surveyet kodede vi først hver for sig i nogle overordnede kategorier om hhv. funktionelle, didaktiske og semantiske læremidler, efterfølgende sammenlignede vi resultaterne og drøftede en yderligere tematisering af de afgivne svar. Vi indledte altså med en lukket kodningsproces, men efterhånden som vi arbejdede os igennem data og koder, måtte vi åbne kategorierne og tilføje eller revidere temaer lidt, og vi fulgte således en velbeskrevet strategi til at etablere et fortolkningsfællesskab i kodningsprocessen (Jacobsen, 2012). På samme måde kodede vi lærerinterviews hver for sig og identificerede tre overordnede temaer på tværs af de seks interviews. Efter endnu en gennemlytning og -kodning af interviewdata blev temaerne bekræftet, men mættet med flere eksempler. Nedenfor gennemgår vi først de overordnede fund fra vores undersøgelse, inden vi ser nærmere på lærererfaringerne med undervisning i mundtlighed, som de træder frem i vores interviewdata.

\section{Overordnede fund}

\section{Rammer for at undervise i sprogfag under nedlukningen}

Vores undersøgelse viser, at sprogfagenes rammer blev ændret med skolenedlukningen: 58\% af respondenterne i vores survey svarede, at der blev læst færre timer i fremmedsprog, da skolerne lukkede ned 11. marts. Ifm. skolernes genåbning for undervisning svarede $44 \%$ at de vendte tilbage til samme lektionstal i fremmedsprog som før nedlukningen, $11 \%$ underviste nu flere lektioner end før nedlukningen 11. marts, mens $37 \%$ stadig underviste færre lektioner. Vores undersøgelse kan ikke sige noget om baggrunden for timereduktionen i sprogfagene, eller om denne situation var særlig for sprogfagene. En af de interviewede lærere fortæller dog, at rammerne for at undervise i sprogfag ændrede sig i løbet af nedlukningen: I begyndelsen var sprogfagene ikke højt prioriteret, i stedet satsede skolen på dansk og matematik - de store fag, kaldte læreren dem. Men efterhånden blev elevernes skoledag arrangeret på nye måder: Skoleskemaet, som passer til en hverdag, hvor elever og lærere går ud og ind ad undervisningslokaler, blev brudt op, og skoledagen arrangeret, så den passede bedre til en digitaliseret undervisning: Nu fik sprogfagene tildelt hele eller halve undervisningsdage i stedet for distribuerede lektioner i løbet af ugen, og dermed blev der mulighed for at rammesætte aktiviteter af en anden karakter, men først og fremmest aktiviteter, som kunne strække sig over længere tid. En anden lærer fortæller i interviewet om, hvordan hun erfarede, at de ændrede rammer og det digitale format stillede krav om tydeliggørelse af rammesætning (især den tidslige faktor):

\footnotetext{
"Vær virkelig tydelig om, hvad planen er. Hav et mødetidspunkt, hvor du forklarer, hvad der skal ske i løbet af dagen - hvor du giver tidspunkter. Hav et sted, hvor det er skrevet ned, så de kan tjekke, hvad er det vi skal på de forskellige tidspunkter, så det hele tiden er tydeligt for dem, at i det her tidsrum, der er det det her, I skal lave, og på det her tidspunkt skal vi mødes igen - eller [det her] tidspunkt, hvor jeg er tilgængelig online, hvornår de skal arbejde alene [...] Så man tager dem i hånden og siger: I skal ikke tænke på andet end at løse opgaven, jeg har styr på planen".
} 
Det digitale format krævede altså en tydelig strukturering af tiden i undervisningen, til gengæld tilbød det fleksibilitet på andre områder, fx i valget af læremidler og teknologier. Det vender vi tilbage til nedenfor.

\section{Opgavetyper}

Et andet interessant resultat fra undersøgelsen af sproglærererfaringer fra nedlukningen er, at opgavetyperne ændrede sig: Vi spurgte til opgavetyperne med samme spørgsmålsbatteri i de to dele af undersøgelsen, og derfor har vi mulighed for at sammenligne, hvad respondenterne svarer om opgavetyperne i de to kontekster. Ikke overraskende falder andelen af lærere, der angiver, at de ofte eller meget ofte bruger digitale teknologier til åbne opgavetyper, som fx projektarbejde fra $75 \%$ til $36 \%$. Lærerne har altså opfattet rammerne for at gennemføre undervisning med den slags opgavetyper som kraftigt forringede under nedlukningen af skolerne. Spørgsmålet melder sig: Hvilke typer af opgaver arbejder eleverne med i stedet for? En hypotese kunne være, at den digitaliserede fremmedsprogsundervisning kommer til at indeholde flere opgaver af repetitiv træningskarakter ( $\mathrm{fx}$ grammatikopgaver, jvf. Kabel et al., 2019), men det kan undersøgelsen ikke bekræfte. Godt nok svarer næsten halvdelen af sproglærerne (48\%), at de ofte eller meget ofte anvender denne type af opgaver under nedlukningen, men noget tyder på, at eleverne faktisk har mødt lidt færre af denne type opgaver under nedlukningen end i den normale sprogundervisning, for her var andelen af lærere, der ofte eller meget ofte satte eleverne til at løse repetitive træningsopgaver $52 \%$. Den antydede tendens genfindes også i vores interviewdata: Her fortæller en lærer, at træningsopgaverne godt nok fyldte en del i undervisningen lige efter d. 11. marts 2020, men at hun fandt især kontekstløse grammatikopgaver meningsløse i de nye rammer, og derfor blev opgaverne efterhånden erstattet af andre opgavetyper i hendes undervisning. En anden lærer fortæller også om erfaringer med træningsopgaver:

"Jeg forsøgte at undgå udfyldningsopgaver, medmindre de havde et formål ind i det, de skulle bruges til. Jeg prøvede på at undgå dem, fordi eleverne drøner igennem dem og husker ikke eller forstår ikke, hvad de har lavet. (...) Det skulle være problemløsende. De skulle kunne se, at det førte hen imod noget, der skulle bruges. Jeg sagde: vi skal kunne det her, når vi er færdige med arbejdet, så skal I kunne lave den her video - og alt det, vi laver indtil da, er for at kunne det".

Onlineformatet har altså betydet et fravalg af repetitive opgavetyper, medmindre de kunne kontekstualiseres.

Undersøgelsen af opgavetyperne viser også, at andelen af aktiviteter med evaluering og feedback øges under nedlukningen, men vel at mærke ikke evalueringer i test- eller quizformater, her falder andelen af lærere, der svarer, at de ofte eller meget ofte anvender disse opgavetyper fra $45 \%$ til $29 \%$. Andelen af lærere, der svarer, at de ofte, eller meget ofte gennemfører opgaver og aktiviteter, der indeholder lærereller elevfeedback, stiger under nedlukningen fra $44 \%$ til $47 \%$. Tallene viser dog, at stigningen især skyldes, at 22\% af lærerne angiver, at de meget ofte anvender disse aktiviteter under nedlukningen mod $13 \%$ i den almindelige undervisning. Vores interviewundersøgelse bekræfter denne tendens: Lærerne angiver, at de under nedlukningen især fik øjnene op for aktiviteter og digitale formater, der gav mulighed for feedback på elevernes mundtlige fremmedsprog. Det vender vi tilbage til nedenfor. I forhold til de ovenfor citerede tidligere undersøgelser af digitale teknologier i undervisningen tyder vores undersøgelse på, at fremmedsprogslærerne begynder at udnytte nogle af de potentialer for fx individualisering (jfr. Lee, 2019), som digitale teknologier tilbyder sprogundervisning, frem for $\mathrm{fx}$ at bruge flere selvrettende, repetitive opgaver, som andre undersøgelser af digitale læremidler i sprogfagene finder (Kabel et al., 2019). 


\title{
Anvendelse af funktionelle læremidler
}

Vores survey undersøgte også, hvilke teknologier, lærerne brugte i forbindelse med nedlukningen. Svarene er afgivet som åbne svar, som vi efterfølgende har kodet med udgangspunkt i læremiddelkategorierne (T. I. Hansen, 2012): Lige under 10\% af lærerne nævner eksempler på læremidler, som vi karakteriser som semantiske (fx film og litteratur på målsproget), lidt flere (12\%) nævner didaktiske læremidler (typisk fagportaler eller hjemmesider, der præsenterer delelementer, $\mathrm{fx}$ grammatiksider), mens hele 64\% af lærerne anfører eksempler på funktionelle læremidler (fx værktøjer til synkron skrivning som fx Padlet og Google doc). Ikke overraskende peger mange af svarene på funktionelle læremider, der understøtter mundtlig kommunikation, fx Zoom, Google Meet, Teams og Skype. Fra denne del af undersøgelsen står det altså ret klart, at det var funktionelle læremidler, der blev taget i brug til at understøtte kommunikationen mellem lærer og elever. Det er et tilbagevendende tema i lærerinterviews, at det digitale format medførte, at lærerne måtte være fleksible i valget af de funktionelle læremidler, og at der var gode erfaringer med at overlade nogle af valgene til eleverne selv:

\footnotetext{
"Du skal have teknisk snilde. Du skal have en nysgerrighed, rent didaktisk skal du have forståelse for, at en plan er en plan, og den kan udvikles sammen med eleverne - sørg for at have elementer, hvor du siger "jeg kan løse det på denne måde, men I må gerne gøre noget andet, hvis det er smart", så man er i stand til at være fleksibel, som underviser. Det betyder ikke, at eleverne bare skal gøre noget, men den vej de skal nå frem til det, de skal aflevere, er fleksibel."
}

En lærer lod sine elever vælge en kommunikationsplatform fra et gamingmiljø til undervisningen og siger om det valg i interviewet:

"8. Klasse spurgte ret hurtigt mig om, vi ikke kunne mødes på Discord. (...) de gik ind og lavede et klasseværelse til mig med grupperum, som bare spillede. (...)

En anden lærer påpeger vigtigheden af, at læreren beholder overblikket over de forskellige teknologiers affordanser og begrænsninger:

\begin{abstract}
"Man skal kunne aflæse, hvad programmet kan i forhold til elevernes udbytte - at have et didaktisk overblik over, hvad det enkelte program kan tilbyde: $\mathrm{Er}$ det et træningsværktøj, er det et evalueringsværktøj, spilværktøj eller er det et åbent værktøj, der gør det, som du har brug for, at det skal gøre. Bookcreator er et fantastisk værktøj, men det kræver, at du kan fylde didaktisk indhold i det".
\end{abstract}

Netop læreres blik for, hvad de konkrete funktionelle læremidler kan, er centralt. De konkrete affordanser for sprogtilegnelse skal med andre ord designes ind i aktiviteterne, som i eksemplet nedenfor:

\footnotetext{
"Eleverne skulle lave en fagbog om frankofone lande i Bookcreator til en 6. klasse. Jeg stillede nogle meget klare krav op om indholdet i hvert kapitel, fx landets navn, symboler, geografi, temperatur, klima. De skulle læse og forstå tekster, der lagde op til det. De skulle forstå noget på fransk og så skulle de skrive det i et sprog, som passede til, at en 6 . klasse ville kunne læse det, og så skulle de lave gloseliste til 6. klasserne. Og det tvang dem jo til at tage stilling til, hvilke ord, der kunne være svære, hvad ville man forstå nemt. Og så fik de feedback af mig med fokus på om en 6. klasse ville kunne læse det. Også fordi, der var nogle, som kørte en tekst gennem google oversæt, som var helt vildt komplekst. Og så sagde jeg: 1, det har du ikke skrevet selv, 2, kunne du læse det, da du gik i 6 . klasse? Nej? Men så må I lige skrive det selv". (...) En 6. klassetrin passer meget godt til det niveau, de kan skrive på i fransk i 8. klasse. I stedet for at skrive komplekse sætninger, fik de øvet mere simple sætningsstrukturer og fik derved også øvet basisgrammatikken."
} 
Opsummerende konkluderer vi på denne del af undersøgelsen, at nedlukningen ikke overraskende betød, at sproglærerne i høj grad kom til at bruge funktionelle læremidler - især værktøjer til kommunikation. Her peger vores undersøgelse på, at selvom lærernes klasseledelse var udfordret af de digitale formater, så opdagede de også nye arbejdsformer og aktiviteter, men det kræver fagdidaktisk opmærksomhed på de forskellige teknologiers affordanser ( $\mathrm{fx}$ brug af Discord som kommunikationsplatform). Af lærerudsagnene fremgår det også, at lærerne gør sig erfaringer med at bruge digitale teknologier til at skabe meningsfulde, kontekstualiserede kommunikationssituationer, hvor eleverne bruger målsproget, fx eksemplet med at skrive om frankofone lande til de yngre elever,

\section{Lærererfaringer med mundtlighed i den digitaliserede fremmedsprogsundervisning}

I forbindelse med vores surveyundersøgelse stillede vi et åbent spørgsmål til lærerne om, hvad de tager med sig af erfaringer fra nedlukningen - gode som dårlige. Her afgav 110 respondenter et svar, og af dem nævnte 40 respondenter eksplicit deres erfaringer med at undervise i mundtlighed i en eller anden form som en positiv erfaring, de tager med videre i deres undervisning. Mundtlighed træder altså frem som et centralt tema i fremmedsprogslærernes erfaringer i vores undersøgelse. Lærerne nævnte både dialogiske former som samtaler mellem lærer og elev, gruppedialoger over teams og lign., men også oplæsning og mundtlige fremlæggelser som aktiviteter, de har gjort sig positive erfaringer med som fremmedsproglærere under nedlukningen. I det følgende ser vi nærmere på de specifikke erfaringer, som lærerne gengiver.

\section{Distribution af taletiden i tryggere rammer}

En lærer valgte at mødes med sine elever i et interaktivt rum knyttet til et gamingmiljø, som eleverne selv foreslog og flere kendte i forvejen:

"8. Klasse spurgte ret hurtigt mig om, vi ikke kunne mødes på Discord. (...) Det vil sige, vi havde et klasseværelse, hvor vi mødtes, hvor vi havde chatfunktion og mikrofonfunktion, intet kamera overhovedet. Jeg kunne godt dele min skærm, men det vigtigste var i virkeligheden, at vi kunne høre hinanden. (...). Og så var det i gang med at tale, og så kunne jeg bare hoppe fra rum til rum, uden at det generede eller forstyrrede dem, og de kunne hele tiden se, hvilket rum jeg var i, så hvis nogen havde brug for spørgsmål, kunne de skrive ude i chatten. Det var bare en gave. Det var nærmest nemmere, end det er ovre i [det fysiske] klasseværelset. "

Det digitale format skabte nogle andre klasseledelsesmuligheder, bl.a. et fleksibelt klasserum med større mulighed for interaktion med underviseren:

"Vi kunne se, hvor hinanden var, men man kunne ikke høre hinanden, medmindre man var puttet ind i den samme lille kasse [grupperum]. De kunne faktisk spørge mig uden at forstyrre mig eller afbryde mig, mens jeg var i gang med at hjælpe nogle andre. Så kunne jeg bare se, der poppede et spørgsmål op. Det var ret mindblowing for mig."

Det valgte funktionelle læremiddel skabte et dynamisk klasserum, som både gav plads til uformel læring - og peer to peer-learning:

"Mange af dem loggede ind om morgenen, før de skulle møde, så sad de og delte skærm med hinanden (...) det er sjovt at få lov at se dem fra en anden side, men også fordi det teknisk muliggjorde, hvis nogen havde behov for at tale med hinanden, så var de lige her. Det var bare så nemt, de kunne skrive sammen i grupperne, men også ude i det store 
klasselokale, så hvis nogen sad i en firemandsgruppe, gav det mulighed for at dele op uden at forstyrre hinanden, og de kunne skrive sammen uden at afbryde alle. Det blev meget effektivt og super dynamisk (...) og det der med, hvis nogen havde tekniske problemer, så lavede de lige en instruktionsvideo. Vi havde slet ikke den der oplevelse af afstand."

Lærerens erfaringer peger på positive erfaringer med at anvende funktionelle lærermidler med særlige affordanser for gruppedialog og interaktion, som distribuerer taletiden og sikrer en vis form for uforstyrrethed i interaktionerne (herunder også fravær af lærerovervågning). Flere af lærerne peger som læreren i uddragene ovenfor - på, at fraværet af kamera støtter elevernes lyst til at bruge målsproget i den digitale undervisning:

\footnotetext{
"Nogle elever har ikke lyst til at optræde på video - de er jo teenagere - de får mulighed for at aflevere en lydfil. "Det vigtigste for mig er ikke [udtalt med emfase] at kunne se dig snakke engelsk, men at høre dig snakke engelsk." Så nogle gange afleverer de bare en lydfil, hvor de har interviewet hinanden (...) Det skal ikke erstatte makkersnak, gruppesnak, og klassesnak og diskussioner. Men det er rigtigt fint at kunne imødekomme dem, der synes, at de der har svært ved at snakke engelsk i timen."
}

Lærererfaringerne peger altså på, at den digitale undervisning har fået dem til at få øje på nogle begrænsninger i den fysiske sprogundervisning, hvor eleverne kan have svært ved at tage ordet på målsproget. En anden lærer siger, at hun overvejer at bruge erfaringerne fra den digitale undervisning til at hjælpe elever, der er udfordret af at sige noget i det fysiske klasserum:

"...[det] overvejer jeg kraftigt med min nuværende 7. klasse, der er så [udtalt med emfase] bange for at fremlægge overfor klassen, selvfølgelig skal de lære det, for det har de brug for i deres videre uddannelsesforløb, (...) men hvorfor så ikke lade dem aflevere en film? Det ville jeg ikke gøre førhen".

Det er i det hele taget et tilbagevendende tema, at den digitale undervisning rummer nogle hidtil uudnyttede muligheder for at få flere elever til at bruge målsproget mere og i flere kontekster:

"Det er en stor udfordring at få eleverne til at producere sprog, det er svært for dem at komme ud over rampen. Det er selvfølgelig envejskommunikation, når de præsenterer noget til mig [i et videoformat], men i de store klasser har de haft dialoger, som de afleverede, hvor der indgik mere frit sprog. Jeg har lagt vægt på at få den kommunikative del ind i det. Det er også det, der er fordelen: Nogle af dem, jeg ikke har hørt sige et ord i virkeligt lang tid, med mindre jeg trækker det ud af dem, eller voldstilladserer dem, får sagt mere på video, end jeg hørt dem sige på et helt skoleår. Efter at disse elever har lavet videoer, er de begyndt at sige mere i klassen. På den måde styrker det deres tro på, at de kan kommunikere."

På baggrund af lærererfaringerne med anvendelsen af mundtlighed i den digitale undervisning vil vi altså konkludere, at lærerne får øje på nogle affordanser i de digitale formater: De digitale teknologier støtter en effektiv distribution af taletiden, hvor elever i tryggere kontekster kan øve det mundtlige målsprog. Lærererfaringerne tyder også på, at anvendelsen af digitale teknologier kan have en effekt på elevernes affektive filter i fremmedsprogsundervisningen. Derudover tyder vores data på, at digitale kommunikationsredskaber giver læreren og andre elever mulighed for at give det, Lee (2019) kalder just-in-time-feedback - både på det sproglige og det tekniske. I det hele taget peger lærerudsagnene på, at valget af et kommunikationsrum, der effektivt kan distribuere taletiden, øger interaktionen i fremmedsprogsundervisningen. Men vi konkluderer også, at lærerne får øje på nogle begrænsninger for brug af målsproget i det fysiske klasserum. Tilstedeværelsen af mange modtagere, fx de andre elever, skaber sociale dynamikker, der ikke nødvendigvis fremmer den frie mundtlighed. Når eleverne øver mundtlighed i en klassesituation, skal de gøre forsøg på målsproget, mens de andre lytter. Det kan være 
svært at eksponere sig selv gennem et fremmedsprog i dette rum (se også Andersen, 2020). Det vender vi tilbage til i vores diskussion nedenfor.

\title{
Fastholdelse og feedback
}

Lærerne rapporterer, at effekten af den digitale undervisning kan aflæses på elevernes færdigheder efter nedlukningen:

\begin{abstract}
"Det gjorde noget ved deres mundtlighed? Ja, helt utroligt, og jeg har sådan gået i det nye år og studset over [det]: Det er egentlig utroligt, så meget den klasse har rykket sig mundtligt - på deres udtale. Vi har jo faktisk arbejdet rigtigt meget med det, uden at jeg har tænkt over det."
\end{abstract}

I lærernes rapporterede erfaringer identificerer vi flere muligheder for at forklare den oplevede positive effekt. Måske bidrager den mere effektivt distribuerede taletid eller det, at eleverne oplever rummet som en tryggere øvebane, som citaterne ovenfor fortæller om, til, at eleverne får sagt mere og dermed bliver dygtigere. Men også det digitale formats mulighed for fordybelse og fastholdelse af mundtligheden kan være en mulig forklaring: Mundtligheden er flygtig, også for læreren, da der samtidig også er andre dagsordner i klasserummet, der kan distrahere. Videoteknologien skaber til gengæld mulighed for at fokusere på sprogbrugeren, og sprogbrugeren får mulighed for at fokusere på at få trænet målsproget:

"[I det fysiske klasserum] kan man hurtigt blive distraheret, men i en video kan man hurtigt spole tilbage og få klarhed over, at det fx kan være th-lydene, som her giver et problem for den enkelte elev, så jeg kan give noget helt konkret feedback på det mundtlige. For eleverne blev det meget en tryghedsting, dels ikke at være synlig for alle - det var jo pludselig så bare en aflevering kun til mig - og at de havde muligheden for at træne, filme og sige: det her synes jeg ikke var godt nok, vi sletter lige og så gør jeg det lige igen. Jeg tror, en del lagde meget mere arbejde i det, fordi de syntes, det skulle være perfekt. Men de havde også selv muligheden for at høre sig selv igen - vi filmer dem jo sjældent, for at de skal høre sig selv igen."

Videoformatet giver også lærerne mulighed for at give præcis og målrettet feedback til den enkelte elev på baggrund af optagelserne:

"Det giver eleverne noget, men det giver også læreren noget i et evalueringsperspektiv "hvad er det, vi skal arbejde videre med?" I hverdagen er det svært at pinpointe, hvor eleverne har udfordringer. Jeg kan godt vurdere, om de er middel, under middel eller over middel, men at sætte ord på, hvad den enkelte præcist kan og ikke kan, det er svært med 28 elever. Med videoerne har jeg et overblik over alle mine elever, nu hvor jeg har skrevet noter og feedback til alle. Du skal arbejde med udtale af det her, husk hvordan du bøjer ordet, du gør det rigtigt flere steder. Det giver mulighed for direkte feedback på det mundtlige, som ellers ofte bliver fluffy i hverdagen."

Samme lærer vil også fremdadrettet bede eleverne lave videopræsentationer og give feedback på disse med henblik på at styrke elevernes selvtillid på målsproget:

"Jeg har lige overtaget en 8. klasse, som havde meget modstand på engelsk. Jeg havde det vitterligt sådan, da de skulle have deres første karakterer, at jeg ikke vidste, hvad jeg skulle stille op. I stedet for at de skulle præsentere i klassen, fik de mulighed for at lave en videopræsentation. Og der hørte jeg noget helt fantastisk engelsk, hvilket også gav mig mulighed for at rose dem "hold fast, hvor er du dygtig til det", "Du kan jo godt", og efter det ville de faktisk sige mere i klassen, så på den måde har det styrket deres tro på, at de faktisk kan kommunikere på et fremmedsprog." 
Citatet ovenfor peger på, hvordan erfaringerne fra nedlukningen let lader sig integrere i den almindelige undervisning, og hvordan læreren konkret har brugt det til at styrke både egne evalueringspraksisser og elevernes oplevelse af sig selv som sprogbrugere.

\section{Diskussion og perspektivering}

Hovedparten af de interviewede fremmedsprogsundervisere fremhæver potentialet ved lyd- eller videoafleveringer som en værdifuld indsigt erhvervet i nedlukningsundervisningen. Vores undersøgelse identificerer altså lyd- og videoafleveringsopgaver som nye veje frem i mundtlighedsundervisningen, men vores analyser peger også på udfordringer i det kommunikative, fysiske klasserum, hvor elever forventes at øve og lære sprog i den almindelige undervisning. Udfordringer, som tidligere forskning også har identificeret (Andersen, 2020). Vores undersøgelse viser, at digitale formater kan afhjælpe nogle af de udfordringer, det fysiske rum stiller nogle elever overfor, $\mathrm{fx}$ ved at sænke det affektive filter (Krashen, 1982). Tidligere undersøgelser peger på, at dette er centralt i forhold til at øge - ikke bare engagementet i fremmedsprogsundervisningen (Piniel \& Csizèr, 2013) - men også sprogfærdigheden (Zhang \& Zou, 2020).

Vi konkluderer endvidere, at den kommunikative sprogundervisning i det fysiske klasseværelse kalder på flere undersøgelser: Kan det organiseres på andre måder med erfaringerne ovenfor in mente? Lærererfaringerne i vores undersøgelse viser, at det asynkrone undervisningsrum har nogle potentialer for fordybelse og fastholdelse af mundtligheden, som ikke udfoldes i den almindelige undervisning i mundtlighed, fx i forbindelse med tasks og gruppearbejde med krav om dynamik og interaktion (Willis, 1996; Pedersen, 2001). Den almindelige klasserumsundervisning kan altså med fordel suppleres af arbejdsformer, der giver rum til individuel fordybelse og til at forholde sig til spørgsmål om fx præcision i sproget. Lærernes erfaringer viser værdien af at give eleverne tid og rum til at øve sig på og reflektere over sprog og over sig selv som sprogbrugere, og lærerne erfarer, at det gør eleverne til mere aktive brugere af målsproget - også uden for de digitale formater. Sammenligner man med det synkrone, fysiske klasseværelse, hvor målsprogets øvebaner tit bliver ulige fordelt og går til elever, der hurtigt kan tænke og formulere et umiddelbart svar, giver erfaringerne med den asynkrone undervisning altså anledning til at sætte spørgsmålstegn ved, om det demokratiserende formål med den kommunikative undervisning (Hymes, 1972; Kramsch, 2006) opfyldes i tilstrækkelig grad: Resultaterne peger på, at der er boehov for at overveje, hvordan deltagelsesmulighederne kan fordeles mere lige, end det er tilfældet nu.

Gennem arbejdet med lyd- og videoafleveringer hæfter de interviewede lærere sig også ved nye muligheder for evaluering og feedback. Ligesom eleverne kan sætte et mere præcist fokus på mundtlige færdigheder ved at indspille, lytte og genindspille, medfører formen også en sproglig detaljegrad, der i den normale undervisning kan være svær for lærere at indfange og sætte ord på. Vores undersøgelser indikerer altså, at sproglærerne har oplevet, at de kunne kvalificere den faglige dialog med eleverne i sprogfagene med de asynkrone, digitale formater for mundtlighed. Selvom konteksten er en anden, finder undersøgelsen af undervisningen på de videregående uddannelser, at denne var præget af en oplevelse af mindre dialog mellem underviser og studerende (Georgsen \& Qvortrup, 2021). Her bidrager vores undersøgelse med et andet resultat af de didaktiske konsekvenser af nedlukningen i foråret 2020.

\section{Konklusion}

Vores undersøgelse viser, at fremmedsproglærerne ikke bare erstattede den fysiske sprogundervisning med tilsvarende digitale formater. I stedet finder lærerne nye potentialer for fremmedsprogsdidaktikken, da de gør sig erfaringer med forskellige kommunikationsredskaber og andre funktionelle læremidler. Lærerne rapporterer med andre ord om nye veje frem for fremmedsprogsdidaktikken, og vores undersøgelse tyder på, at lærerne lader nogle af erfaringerne fra 
skolenedlukningerne informere og kvalificere deres eksisterende praksisser, fx i forbindelse med undervisning i mundtlighed men også i forbindelse med inddragelse af teknologier, der øger motivation for og interaktion på målsproget. Vi vurderer, at det vigtigste fund fra vores undersøgelse af fremmedsprogslærernes erfaringer fra skolenedlukningen i forået 2020 angår de digitale teknologiers potentialer for at sænke det affektive filter i forbindelse med undervisning i mundtlighed. Det kan synes paradoksalt, at den digitaliserede fremmedsprogsundervisning viste nye veje frem for mundtlighed, som vi traditionelt forbinder med elever og læreres fysiske tilstedeværelse i fremmedsprogsundervisningen, men de asynkrone arbejdsformer med lyd- eller videoafleveringer har vist sig at have potentialer for at motivere og gøre elever mundtligt trygge, for at skabe rum for fordybelse og for at arbejde med sproglig præcision og sproglig bevidsthed og endeligt også for nye evaluerings- og feedbackpraksisser. Der kan være grund til at tro, at både læremiddellandskabet (J. J. Hansen, 2010) og sprogdidaktikken vil være forandret, når alle coronaerfaringer er kendt.

Undersøgelsen er finansieret af Det Nationale Center for Fremmedsprog, NCFF. Tak til NCFF og til de deltagende lærere. 


\section{Referencer}

Andersen, L. K. (2020). Mundtlighed i fremmedsprogsundervisningen. Pædagogisk Indblik nr. 5, 2020. Aarhus Universitetsforlag.

Andersen, L. H.; Fernández S. S.; Fristrup, D.; Henriksen, B. (2015). Fagdidaktik i sprogfag. Frydenlund.

Anderson, M. \& Larsen-Freeman, D. (2011). Techniques and principles in language teaching (3rd edition). Oxford University Press.

Boie, M. A. K., Dalsgaard, C. \& Caviglia, F. (2020). Det digitale instinkt. Tidsskriftet Læring \& Medier (LOM), nr. 23 - 2020.

Bremholm, J., Bundsgaard, J., Fougt, S. S., \& Skyggebjerg, A. K. (2017). Danskfaget set gennem dets læremidler. In J. Bremholm, J. Bundsgaard, S. S. Fougt, \& A. K. Skyggebjerg (Eds.), Læremidlernes danskfag. Aarhus Universitetsforlag. (pp. 7-27).

Bundsgaard, J., Georgsen, M., Graf, S. T., Hansen, T. I., \& Skott, C. K. (2018). Forskning i tre demonstrationsskoleforsøg. In J. Bundsgaard, M. Georgsen, S. T. Graf, T. I. Hansen, \& C. K. Skott (Eds.), Skoleudvikling med IT. Aarhus Universitetsforlag. (pp. 7-15).

Bundsgaard, J., \& Hansen, T. I. (2018). Blik på undervisning. In J. Bundsgaard, M. Georgsen, S. T. Graf, T. I. Hansen, \& C. K. Skott (Eds.), Skoleudvikling med IT. Aarhus Universitetsforlag. (pp. 106-142).

Burner, T. \& Kverndokken, K. (2019). "Communicative Competence in The English Classroom". I Burner, T., Carlsen, C., Kverndokken, K. (Red.) 101 ways to work wth communicative skills. Fagbokforlaget

Burns, Anne. (2019). Concepts For Teaching Speaking in the English Classroom. LEARN Journal 12 (1). (pp. 1-11).

Canale, M. \& Swain, M. (1980). Theoretical Bases of Communicative Approaches to Second Language Teaching and Testing. Applied Linguistics 1. (pp. 1-47.)

Caviglia, F., Dalsgaard, F., Boie, M. A. K \& Thomsen, M. B. (2021). Undersøgelse af digitale teknologier i fremmedsprogsundervisningen - Sproglæreres anvendelse af digitale teknologier i gymnasiet. DPU Danmarks Institut for Pædagogik og Uddannelse, Aarhus Universitet. https://pure.au.dk/portal/files/213331375/FREMDitSPROG_sporgeskemaundersogelse_marts2021.pdf.

Frederiksen, M. (2013). Mixed methods-forskning - fra praksis til teori. I: Gundelach, P., Nielsen, R. S. \& Frederiksen, M. (Red.), Mixed methods-forskning: principper og praksis. Hans Reitzel. (pp. 9-34)

Georgsen, M., \& Qvortrup, A. (2021). Erfaringer og oplevelser med onlineundervisning på 9 videregående uddannelsesinstitutioner i foråret 2020.

Golonka, E. M., Bowles, A. R., Frank, V. M., Richardson, D. L. \& Freynik, S. (2014) Technologies for foreign language learning: a review of technology types and their effectiveness, Computer Assisted Language Learning, 27:1. (pp. 70-105). DOI: 10.1080/09588221.2012.700315

Hansen, J. J. (2010). Læremiddellandskabet-Fra læremiddel til undervisning. Akademisk Forlag.

Hansen, K. M. (2012). Spørgeskemadesign. I: Andersen, L. B., Hansen, K. M. \& Clemmensen, R. (red.), Metoder i statskundskab. Hans Reitzels Forlag. (pp. 287-301).

Hansen, T. I., \& Bundsgaard, J. (2016). Effektmåling af demonstrationsskoleforsøg: Afrapportering af kvantitative undersøgelser på tværs af de tre demonstrationsskoleprojekter i AUUC-konsortiet. (1 udg.).

Hansen, T. I. (2012). Semiotik og læremidler. I Graf, S. T., Hansen, J. J., \& Hansen, T. I. (Eds.), Læremidler i didaktikken. Klim. (pp. 135-162).

Harmer, J. (2015). The practice of english language teaching (5th edition). Pearson.

Hedge, T. (2000). Teaching and learning in the language classroom. Oxford University Press.

Hymes, D. (1972). On communicative competence. I Pride, P. B., \& Holmes, J. (Eds.), Sociolinguistics: Selected Readings. Penguin. (pp. 269-293).

Høegh, T. (2018). Mundtlighed og fagdidaktik. Akademisk Forlag.

Jacobsen, M. L. F. (2012). Kvalitativ analyse: kodning I: Andersen, L. B., Hansen, K. M. \& Clemmensen, R. (red.), Metoder i statskundskab. Hans Reitzels Forlag. 173-210.

Kabel, K., Christensen, M. V., \& Brok, L. S. (2019). Hvordan - praktiseres grammatikundervisning i dansk , engelsk og tysk? Statusrapport Gramma3 (p. 143). Nationalt Videncenter for Læsning.

Kramsch, C. (2006). From communicative competence to symbolic competence. The Modern Language Journal, 90(2). (pp. 249-252).

Krashen, S. D. (1982). Principles and practice in second language acquisition. Pergamon Press.

Kvale, S. \& Brinkmann, S. (2015) Interview. Hans Reitzel.

Lee, S.-M. (2019): A systematic review of context-aware technology use in foreign language learning, Computer Assisted Language Learning, DOI: 10.1080/09588221.2019.1688836

Lightbown, P. M. \& Spada, N. (2013). How languages are learned (4th edition). Oxford University Press.

Lund, K. (2015). Fokus på sprog. I Gregersen, A. S. (Red.) Sprogfag i forandring, Samfundslitteratur. (pp. 87-128). 
MacIntyre, P. D. (2007). Willingness to communicate in the second language: Understanding the decision to speak as a volitional process. The Modern Language Journal, 91 (4). (pp. 564-576).

Pedersen, M. (2001). Task Force-Et bud på kommunikativ sprogundervisning. Sprogforum, 20(7), 7-19.

Penne, S., \& Hertzberg, F. (2019). Mundtlige tekster i klasserummet. Dansklærerforeningens forlag. Pérez, N. P. C. (2016). Effects of Tasks on Spoken Interaction and Motvation in English Language Learners. Gist Education And Learning Research Journal 13. (pp. 34-55).

Piniel, K., \& Csizér, K. (2013). L2 motivation, anxiety and self-efficacy: The interrelationship of individual variables in the secondary school context. Studies in Second Language Learning and Teaching, 3(4), 523. https://doi.org/10.14746/ssllt.2013.3.4.5

Scrivener, J. (2011). Learning teaching: The essential guide to English language teaching (3rd edition). Macmillan Slot, M. F., Hansen, R., \& Bremholm, J. (n.d.). Elevopgaver og elevproduktion i det 21. århundrede. En kvantitativ og kvalitativ analyse af elevproduktion i matematik, dansk og naturfag. Laeremiddel.dk

Tannert, A. M., \& Berthelsen, U. D. (2020). Digitale læremidler i danskfaget. Pædagogisk Indblik nr. 4, 2020. Aarhus Universitetsforlag.

Willis, J. (1996). A framework for task-based learning. Longman.

Zhang, R. \& Zou, D. (2020) Types, purposes, and effectiveness of state-of-the-art technologies for second and foreign language learning, Computer Assisted Language Learning. DOI: $\underline{10.1080 / 09588221.2020 .1744666}$ 


\section{Forfattere}

\section{Mette Vedsgaard Christensen}

Ph.d., Docent og forskningsleder

VIA University College

Program for Sprog og Literacy

\section{Alice Bonde Nissen}

Lektor

VIA University College

Program for Læring og IT

\section{Morten Gustenhoff}

Adjunkt

VIA University College

Program for Sprog og Literacy
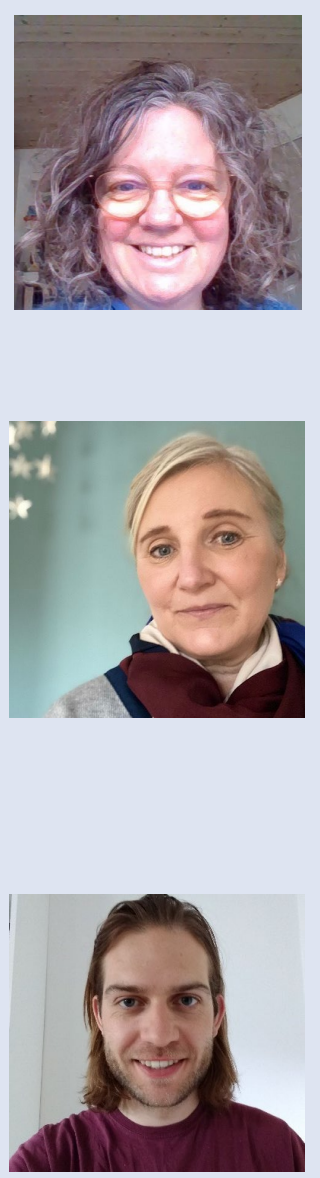